International Journal of Agriculture, Environment and Bioresearch

Vol. 5, No. 01; 2020

ISSN: $2456-8643$

\title{
YIELD OF ORGANIC RICE AS AFFECTED BY AZOLLA AND BIOFERTILIZER AMENDMENT TO RICE STRAW AS ORGANIC FERTILIZER FOR SUSTAINABLE LOWLAND RICE PRODUCTION
}

\author{
Mieke Rochimi Setiawati ${ }^{1}$, Pujawati suryatmana ${ }^{1}$, Diyan Herdiyantoro ${ }^{1}$, Ana Maulidya Ramdani ${ }^{2}$ and Nadia \\ Nuraniya Kamaluddin ${ }^{1}$ \\ ${ }^{1}$ Soil Science Department, Agriculture Faculty of Universitas Padjadjaran, Indonesia. \\ ${ }^{2}$ Undergraduate student, Soil Science Department, Agriculture Faculty of Universitas Padjadjaran, Indonesia \\ https://doi.org/10.35410/IJAEB.2020.5481
}

\begin{abstract}
Rice is a stapple food consumed by most Indonesian people. Increasing the number of residents encourages an increase in rice production, so land intensification needs to be done. Now, the trend of a healthy lifestyle that is environmentally friendly encourages the creation of organic farming. The effort of keeping the nutrient needs at the organic agriculture could be applied with rice straw and Azolla utilization. This research was intended to find out the best dosage combination of organic fertilizer and biofertilizer to total nitrogen, chlorophyll content, and yield of rice. The experiment used randomized block design (RBD) which consisted of six treatments and four repetitions, that was combination of organic fertilizer, Azolla, solid biofertilizer, and liquid biofertilizer. The variabel observed was nitrogen content of soil, chlorophyll content, and crop yields. The research result shows that application of rice straw compost 10 ton ha- 1 with liquid biofertilizer $5 \mathrm{~L}$ ha- 1 can increase the rice yield up to 6.01 ton ha-1, it was almost twice compare with farmer practise which is use only rice straw compost. Addition of azolla 7.5 tons ha-1 in the previous treatment did not increase rice yields and even obtained the same rice yield but it was useful for maintaining soil quality and increasing rice yield next planting season.
\end{abstract}

Keywords: organic fertilizer, biofertilizer, Azolla, organic rice.

\section{INTRODUCTION}

Rice is stapple food consumed by Indonesians. According to Central Bureau of Statistics data (2018), national production of rice in Indonesia increases every year. Recorded national production of rice in 2017 is 81.38 million tons. The citizen population in Indonesia in 2017 is 262 million people, therefore, the consumption rate of rice is $114.6 \mathrm{~kg} / \mathrm{capita} / \mathrm{year}$. This shows that rice consumption rate is rising along with the increase of population. Indonesian Directorate General of Food Crops (2018) stated that environmentally friendly healthy lifestyle trend is currently improving in the society and has been institutionalized internationally that indicates requirement of safe to be consumed, highly nutritious, and environmentally friendly for agriculture products.

One of the efforts of the last decade to give hope is the application of SRI (System of Rice Intensification) in rice cultivation. Various research reports and farmers cultivation results show 
an increase in yields of up three fold. SRI is a method in rice cultivation that has the potential to increase rice productivity by changing the planting system, plant spacing, water delivery, and fertilizer use. Barkelaar (2001) stated that the advantages of rice cultivation with the SRI method include: water saving, being cost-effective, time-saving, saving seed, being environmentally friendly, and increased production. SRI is prioritizes local potential and categorized as environmentally friendly agriculture. SRI rice implementation in several region of West Java is carried out organically without the dependence on inorganic fertilizer and chemical pesticide. According to Aktaviani and Syamsudin (2008) the implementation of organic rice cultivation in Sukakarsa-Tasikmalaya village, West Jawa requires compost in large quantities around 10 tons ha-1.

As one of essential nutients for crops, Nitrogen affects crops growth, moreover in vegetative growth phase and holding important role of the chlorophyll formation (Sumiati \& Gunawan, 2007). Alternative of organic material source for supplying the needs of organic fertilizer in organic rice cultivation process is by utilizing rice straw and Azolla. During the cultivation of rice crops, the production of rice straw can be as high as 7 to 10 tons ha-1 in each planting season (Mandal et.al., 2004). Kumar (2008) said that rice straw have ratio C:N 80:1, C-Organic $51.76 \%$, Nitrogen $0.65 \%$, Phosphorus $0.20 \%$, Potassium $0.30 \%$ and is rich of silica and lignin. Numerous experiments have indicated that soil application of organic manure will improve its physical properties, chemical characteristics (Soda et al., 2006), and fertility status (Maftoun and Moshiri, 2008).

Amendment organic fertilizer 7.5 tons ha-1 added with solid bio-fertilizer Azolla-based $10 \mathrm{~kg}$ ha-1 and applied a week before cultivation have 6.583 tons ha-1 dried unhulled rice harvest yied and higher compared to farmers practise on organic rice system. Applicating organic and solid bio-fertilizer also brings prospect of yield improvement of organic rice in Cisayong Tasikmalaya Region as organic rice central in West Java, (Setiawati et al., 2019).

Azolla is a free floating aquatic water fern which grows at a fast rate doubling its biomass in 3-5 days and fixes atmospheric nitrogen by forming a symbiotic association with the blue-green algae Anabaena azollae (Bhuvaneshwari and Kumar, 2013). The beneficial effect of the Azolla showed that it increases soil organic matter, improved soil and supply fixed nitrogen. After its decomposition, humus is formed which increases the water holding capacity of the soil and promotes aeration and drainage. Azolla supply fixed nitrogen and increases the uptake of some nutrient element such as Calcium, Magnesium and potassium (Sinha et al., 2002). Application of Azolla has been found to significantly improve the physical and chemical properties of the soil especially nitrogen, organic matter and other cations such as Magnesium, Calcium and Sodium released into the soil (Bhuvaneshwari and Kumar, 2013). Biofertilizer from azolla can be made from extract Azolla which rich of growth-promoting substances. Bindhu (2013) satate that the biofertilizer Azolla extract is having good fertilizer activity. The extract acts as a desirable biological fertilizer supplement to chemical fertilizer for organic farming. The extract is non toxic, harmless, non flammable and effective to all plants for attaining better germination, growth and yield. 
Residual effects of organic fertilizer application were manifested with an increase in soil nutrient availability during the second season. This led to better plant growth, higher dry matter production, improved LAI, and higher plant tissue content of nitrogen and phosphorus. Similar data have been reported by Buri et al. (2004) and Man et al. (2009). Therefore, a research of impact of combination from rice straw, cow manure and Azolla with solid and liquid biofertilizer toward nitrogen content of soil, chlorophyll content, and rice yield is needed.

\section{MATERIALS AND METHODS}

This research was conducted in Experimental field of Agriculture Faculty Universitas Padjadjaran, Jatinangor, West Java. The soil texture was silty clay; low fertility soil which was slight acid ( $\mathrm{pH}$ 6.24). Chemical characteristics of soil were high in organic carbon (3.01\%), moderate in total Nitrogen $(0.28 \%)$ and available P2O5 $(1.17 \mathrm{mg} / \mathrm{kg})$, high in total P2O5 (134.63 $\mathrm{mg} / 100 \mathrm{~g})$, and moderate in total $\mathrm{K} 2 \mathrm{O}(11.30 \mathrm{mg} / 100 \mathrm{~g})$.

Materials required in this research were rice seed of Ampera varieties, biofertilizer consortium bacteria of nitrogen-fixing bacteria (Azotobacter sp., Azosprillum sp., N-fixing

Endophytic bacteria) and phosphate solubilizing bacteria, carrier such as Azolla compost for solid biofertilizer and liquid biofertilizer have ingredient $2 \%$ of mollases + Azolla extract + consortium bacteria, organic fertilizer as rice straw with cow manure (4:1) compost, and fresh Azolla. Amendment dosage of rice straw and cow manure compost was 10 tons ha-1 (farmer practise), Azolla 7.5 tons ha-1, Solid Biofertilizer $10 \mathrm{~kg}$ ha-1, and Liquid Biofertilizer $5 \mathrm{~L}$ ha-1. Rice straw compost and azolla was incorporated in the soil as a basal fertilizer at 1 week before transplanted rice plant. At two week after planted rice plant, solid or liquid biofertilizer was incorporated as top dressing or foliar treatment and repeated every one week until 5 weeks after planted.

Design used for this research was Randomized Block Design (RBD) consisted of combination treatment of organic and biofertilizer. The combination made were 6 combinations and repeated 4 times that made 24 experimental plots.

$\mathrm{A}=$ rice straw compost (farmers practise) $\mathrm{B}=$ rice straw compost + Azolla

$\mathrm{C}=$ rice straw compost + Solid Biofertilizer

$\mathrm{D}=$ rice straw compost + Azolla + Solid Biofertilizer $\mathrm{E}=$ rice straw compost + Liquid Biofertilizer

$\mathrm{F}=$ rice straw compost + Azolla + Liquid Biofertilizer

Each plot measures $2 \times 4$ meters with planting distance for each crop $25 \times 25$ centimeters.

The sampling of Total-N soil, crops chlorophyll content were analysis on 6 Week After Planting (WAP), the yield was collected after panicle were yellow ripe from each plot on 16 WAP. All data were subjected to analysis of variance (F test) at $\mathrm{P}<0.05 \%$ followed by Duncan's Multiple Range Test if the effect of treatments on experimental parameters was significant. 
Vol. 5, No. 01; 2020

ISSN: $2456-8643$

\section{RESULTS AND DISCUSSION}

\section{Nitrogen Content of Soil}

Based on data result of statistics test of total-N soil, it discovers that no single treatment has significant impact on the crops as being stated in Table 1. Compared to the previous of total-N soil which was $0.28 \%$, for every treatment there is no increase of total-N soil after the application of organic fertilizer treatment and combination of organic with biofertilizer slight decreased in total-N soil instead.

Decrease of total-N soil was caused by the analysis of total-N soil performed while the crops entering maximum vegetative phase. Nitrogen plays significant role in vegetative phase of crops because it is needed for crops growth (Rahman, et.al., 2009). Although one of the advantages of choosing Azolla from any other organic fertilizer is the higher of $\mathrm{N}$ content by 3-5\% (Hartadi and Ngadiman, 1995). However in vegetative phase, crops absord a lot of nitrogen from the soil, moreover it is suspected that nitrogen as nutrients has been assmilated by microbes in biofertilizer or organic fertilizer for forming protein, nucleic acid, also microbes cell wall (Nurrizki, 2012). Decrease of nitrogen nutrients in soil is also believed to be the effect of immobilization and ammonium fixation which makes nitrogen would not be sufficient for crops temporarily (Ismunadji and Roechan, 1998).

Table 1. Impact of Organic Fertilizer and BioFertilizer Combination on Total-N Soil and Chlorophyll Content

\begin{tabular}{|l|l|c|}
\hline \multicolumn{1}{|c|}{ Treatments } & Total-N (\%) & $\begin{array}{c}\text { Chlorophyll Content } \\
\text { (CCI) }\end{array}$ \\
\hline $\mathrm{A}=$ rice straw compost (farmers practise) & 0.25 & 17.41 \\
\hline $\mathrm{B}=$ rice straw compost + Azolla & 0.24 & 17.58 \\
\hline $\mathrm{C}=$ rice straw compost + Solid Bio-Fertilizer & 0.25 & 17.16 \\
\hline $\mathrm{D}=$ rice straw compost + Azolla + Solid Bio-Fertilizer & 0.25 & 16.73 \\
\hline $\mathrm{E}$ = rice straw compost + Liquid Bio-Fertilizer & 0.24 & 17.53 \\
\hline $\mathrm{F}=$ rice straw compost + Azolla + Liquid Bio-Fertilizer & 0.21 & 17.36 \\
\hline
\end{tabular}

Notes : Numbers in a column were not significantly differ based on 5\% Duncan's Multiple Range Test.

\section{Chlorophyll Content}

In organic rice production systems have increased the use of organic fertilizers in an attempt to produce and sustain high crop yields. Symptoms of insufficient N supply, which is one of the most critical nutrients in crop production, include lower chlorophyll content, less biomass production, and a decreased grain yield and quality (Prasertsak and Fukai, 1997). Singh et al, (2002) told leaf $\mathrm{N}$ content is strongly correlated with chlorophyll content. Observation of chlorophyll content in leaves was performed during rice crops in its maximum vegetative phase. According to this experiment there is no significant effect of chlorophyll content for all treatments as shown in the Table 1. Hendriyani and Setiari (2009) claimed several factors that 
affect chlorophyll synthesis in plants are genetics, light, oxygen, carbohydrate, Nitrogen, Magnesium, Fe, Mn, Zn, Cu substances in a small amount, water, and temperature (26-30 0C).

The infuence of irradiance on chlorophyll meter measurements may be species-specifc, depending on species adaptation to high irradiance (Mamrutha et al. 2017). Regarding the canopy refectance sensors, the capacity of the vegetation indices to diferentiate $\mathrm{N}$ nutrition in vegetables, is consistent with results with tomato (Gianquinto et al. 2011), hydroponicallygrown (Yang et al. 2010) and soil-grown cucumber (Padilla et al. 2017).

Water is one of limiting factors in chlorophyll forming. When plants face water deficiency, some stomata will close itself and block CO2 needed for photosynthesis process to enter (Salisbury and Ross, 1995; Banyo, et.al., 2013). The disturbance of photosynthesis process will slow down its pace. During the experiment, rainfall rate was very low, causing disturbance on chlorophyll forming process for not being maximal. Besides, the absorption of nutrients was hampered that affected availability of $\mathrm{N}$ and $\mathrm{Mg}$ substances that are very crucial for chlorophyll synthesis (Syafi, 2008).

In this research, the role of microbes in biofertilizer for increasing chlorophyll forming in leaves have not yet effective compared to treatment of organic fertilizer with Azolla combined. This was caused by the microbes activity to fix nitrogen has not been optimal at 6 Week After Planting (WAP) or 42 Day After Planting (DAP) on chlorophyll analysis was taken. Gholizadeh et al. (2017) stated that chlorophyll meter values were closely related to grain yield at both growth stages, especially at panicle formation (55-60 DAP). It is suspected that when chlorophyll analysis is carried out at 60 DAP there will be a difference between treatments because the activity of $\mathrm{N}$-fixing microbial has been optimal.

\section{Rice Grain Yield}

\section{The 1000 Grains Weight}

Statistics analysis has shown in Table 2 that combination of organic fertilizer and biofertilizer did not significantly affect 1000 grains weight. Generally, there was inclination of increase of 1000 grains weight in all treatments. In characteristics description of Ampera rice variety is known the average1000 grains weight of Ampera variety is 23.40 grams. However, the application of organic fertilizer and biofertilizer at this experiment can increase the 1000 grains weight. The increase of grains weight was found caused by sufficient supply of nutrients during vegetative and generative phase. The results of the analysis show that there is no significant difference between treatments on 1000 grains weight. However, the grain size character was influenced by genetic characters. The grain size characteristics of a variety may be different from other varieties and this is very influential on grain weight (Lee et al., 2015).

The positive impact of organic fertilizers on soil fertility improvement might be due to the following relationships. First, decomposition and mineralization of nutrients present in the organic matter. Second, release of some organic acids as a result of organic decomposition, which reduces the soil $\mathrm{pH}$ while improving nutrient availability. Similar arguments are supported by Lithourgidis et al. (2007). Third, and most importantly, enhancing soil functional stability 
mediated by soil microbial community (Girvan et al., 2005). Plant productivity is linked closely to organic matter (Bauer and Black, 1994).

As being explained in variable yield of rice that $\mathrm{N}, \mathrm{P}$ and $\mathrm{K}$ substances affect grain yield. High content of nitrogen absorbed by crops in that treatment may accelerate photosynthesis rate. In this case, a photosynthesis process that runs well will impact good amylum forming because 1000 grains weight depends on amylum content stored in grains (Riyani, 2013).

Tabel 2. Effect of organic fertilizer and biofertilizer combination on rice yield

\begin{tabular}{|c|c|c|c|}
\hline Treatment & $\begin{array}{l}1000 \text { grains } \\
\text { weight }(\mathrm{g})\end{array}$ & $\begin{array}{l}\text { Rice Yield } \\
\left(\mathrm{g} \mathrm{m}^{1}{ }^{1}\right)\end{array}$ & $\begin{array}{c}\text { Rice Yield } \\
\text { (ton } \mathrm{ha}^{-1} \text { ) }\end{array}$ \\
\hline $\mathrm{A}=$ rice straw compost (farmers practise) & 29.75 & $414 \mathrm{a}$ & $3.31 \mathrm{a}$ \\
\hline $\mathrm{B}=$ rice straw compost + Azolla & 30.25 & $602 \mathrm{bc}$ & $4.82 \mathrm{ab}$ \\
\hline $\mathrm{C}=$ rice straw compost + Solid Biofertilizer & 30.25 & $608 \mathrm{bc}$ & $4.86 \mathrm{ab}$ \\
\hline $\mathrm{D}=$ rice straw compost + Azolla + Solid Biofertilizer & 30.50 & $456 \mathrm{ab}$ & $3.65 \mathrm{a}$ \\
\hline $\mathrm{E}=$ rice straw compost + Liquid Biofertilizer & 29.50 & $751 \mathrm{c}$ & $6.01 \mathrm{bc}$ \\
\hline $\mathrm{F}=$ rice straw compost + Azolla + Liquid Biofertilizer & 31.50 & $682 \mathrm{bc}$ & $5.46 \mathrm{~b}$ \\
\hline
\end{tabular}

Notes : Numbers in a column followed by same letters were not significantly differ based on 5\% Duncan's Multiple Range Test.

\section{Rice Yield}

The application of combination of organic and biofertilizer had improve the yield of rice yield. In controlled treatment or farmers practise, organic rice reaches GKP amount of $414 \mathrm{~g} \mathrm{~m}-1$ or 3.31 ton ha-1. Whereas the treatment of organic matter from rice straw compost added with azolla causes an increase in rice yield. Gaind and Lata (2010); Jha et al. (2012) told that organic amendments positively affect the soil fertility parameters, thereby influencing the soil productivity.

Rice straw compost with liquid Biofertilizer amendments produced the highest rice yield compared to other treatments it was $571 \mathrm{~g} \mathrm{~m}-1$ or 6.01 ton ha-1. The addition of azolla to the treatment mentioned earlier did not cause an increase in rice yield or the yield did not differ from without amendment Azolla. Although Baig et al. (2004) have stated that applying organic manure up to $10 \mathrm{t}$ ha- 1 significantly enhanced rice growth and yield contributing traits as well as grain yield and grain nutrient content. The applied of azolla to straw compost which given before planting plant rice causes the availability of nutrient $\mathrm{N}$ quickly used by rice plants at the vegetative phase. Whereas liquid biofertilizer was given every week to rice plant provides nutrient availability continuously. Biofertilizer provides $\mathrm{N}$ and $\mathrm{P}$ for rice plant due to the activity of $\mathrm{N}$-fixing and phosphate solubilizing bacteria.

The Addition of azolla 7.5 tons ha-1 in rice straw compost with liquid biofertilizer treatment (F) did not increase rice yields and even obtained the same rice yield however the yield is almost twice compare with the farmers practise, by adding only straw compost. This indicates that organic rice yields can still be improved by adding organic matter both azolla and liquid 
biofertilizers. Azolla can suply $\mathrm{N}$ and macro-micro nutrient to the soil and also growth promoting subtances which needed the plant growth. However the effect of increasing the yield as amendment Azolla is predicted in the next planting season because the addition of azolla can increase the organic $\mathrm{C}$ content of the soil which acts as a nutrient buffer in the soil. While addition liquid biofertilizer is complete $\mathrm{N}$ and $\mathrm{P}$ nutrient requirements supplied from $\mathrm{N}$ - fixing bacteria and phosphate solubilizing bacteria.

Rice yied is also influenced by photosynthesis process of plants, in which the process itself depends on $\mathrm{N}, \mathrm{P}$ and $\mathrm{K}$ substance as nutrients. $\mathrm{N}$ substance takes important role to form protein that will be used by crops to increase amount of panicles per clump. In generative phase, however, $\mathrm{P}$ and $\mathrm{K}$ substance take more active role. $\mathrm{P}$ substance actively supplies and transfers energy in all biochemical processes such as accelerating ripening process and stimulating crops growth, so it will improve quality and weight of crops (De Datta, 1981).

The effect of applying organic fertilizer usually does not show immediate results because the effect can improve the physical properties of the soil and support plant nutrients more available in the next planting season. Lanna et al. (2018) said that the residual effect of organic compost was confirmed by the increasing on plant production in initial "high" soil fertility area. Arunrat et al. (2017) said that in order to achieve sustainable management of rice fields in tropical monsoon climates, it is necessary to understand current soil properties and land management practices to develop alternative management practices for maintaining soil quality and increasing in rice yield to ensure food security for the food demands of the growing population.

\section{CONCLUSIONS}

According to the research conducted, conclusion is application of rice straw compost 10 ton ha-1 with liquid biofertilizer $5 \mathrm{~L}$ ha-1 can increase the rice yield up to 6.01 ton ha-1 compare with farmer practise was almost twice which is use only rice straw compost. Addition of azolla

7.5 tons ha- 1 in the previous treatment did not increase rice yields and even obtained the same rice yield but it was useful for maintaining soil quality and increasing in rice yield next planting season.

\section{Acknowledgements}

The authors is thankful for the Ministry of Research, Technology and Higher Education of the Republic of Indonesia for providing the funds this research through STRANAS (Strategic National) research scheme 2018.

\section{REFERENCES}

Aktaviyani, S. and Syamsudin T.S. 2008. Organic rice farming as one solution towards the realization of food security and public health. National Proceedings Postgraduate Student Symposium Theme: 100 years of National Awakening in Various Perspectives. pp. 311-320. Yogyakarta. 
Arunrat N., Pumijumnong N., and Hatano R. 2017. Practices sustaining soil organic matter and rice yield in a tropical monsoon region, Soil Science and Plant Nutrition, 63:3, 274-287.

Baig, M.B., M.S Zieeidan and Mabler S. 2004. Effect of sesbania (Sesbania aculeata) and farmyard manure. Arab Gulf J. of Scientific Research 22(2): 51-59.

Banyo Y.E., Ai N.S., Siahaan P., Tangapo A.M. 2013. Chlorophyll concentration of rice leaves during water shortage induced by polyethylene glycol. Jurnal Ilmiah Sains. 13 (1):1-8.

Berkelaar, D. 2001. System of Rice Intensification-SRI: Some can provide more. ECHO Newsletter Development Notes, Inc. 17.391 Durrance Rd. North FtMyers FI.33917 USA.

Bauer, A. and Black A.L. 1994. Quantification of the effect of soil organic matter content on soil productivity. America J. of Soil Science Society, 5: 185-193.

Bhuvaneshwari K and Kumar A. 2013. Agronomic potential of the association Azolla Anabaena. Science Research Reporter. 3(1): 78-82.

Bindhu K.B. 2013. Effect of Azolla Extract on Growth Performance of Pisum sativum. International Research Journal of Biological Sciences Vol. 2(10), 88-90.

Buri, M.M., Issaka R.N., Wakatsuki T. and Otoo E. 2004. Soil organic amendments and mineral fertilizers: options for sustainable lowland rice production in the forest agro-ecology of Ghana. Agric. \& Food Sci. J. of Ghana 3: 237-248.

Central Bureau of Statistics Data. 2018. Rice production by province (tons), 1993-2015. Jakarta Indonesia : Central Statistics Agency.

De Datta, S. 1981. Principle and practices of rice production. John Wiley \& Sons. New York. USA.

Gaind S., and Lata N. 2010. Exploration of composted cereal waste and poultry manure for soil restoration. Bioresource Technol 101 (3): 2996-3003.

Gholizadeh A., Saberioon M.M., Borůvkaa L., Wayayok A., and Soom M.A. 2017. Leaf chlorophyll and nitrogen dynamics and their relationship to lowland rice yield for site-specific paddy management. Information Processing in Agriculture. Volume 4, Issue $4: 259-268$.

Gianquinto G., Orsini F., Fecondini M., Mezzetti M., Sambo P., and Bona S. 2011. A methodological approach for defning spectral indices for assessing tomato nitrogen status and yield. European Journal of Agronomy. 35, 135-143.

Girvan M.S., Campbell C.D., Killham K., Prosser J.I., and Glover L.A. 2005. Bacterial diversity promoted community structure stability and functional resilience after perturbation. Environmental Microbiology 7: 301-313.

Hartadi, S. And Ngadiman, 1995. Azolla as soil amendment material. Laboratory of Microbiology, Faculty of Agriculture, Universitas Gadjah Mada. Yogyakarta. 
Vol. 5, No. 01; 2020

ISSN: $2456-8643$

Hendriyani I.S. and Setiari N. 2009. Chlorophyll content and growth of string beans (Vigna sinensis) at different water supply levels. J. Science and Math, Vol, 17(3): 145-150.

Indonesian Directorate General of Food Crops. 2018. Technical guidelines for developing organic rice farming villages in 2016. Jakarta: Directorate General of Food Crops, Indonesian Ministry of Agriculture.

Ismunadji M. and Roehan S. 1998. Mineral nutrient of rice plants. pp 231-264. in Ismunadji

M. et al. (Eds). Paddy. Book I. Indonesian Center for Agriculture Research and Development, Center for Food Crop Research and Development. Bogor.

Jha M.N., Sanjeet C., and Sinha S. 2012. Microbial consortium for sustainable rice production. J Sustainable Ag. 36: DOI:10.1080/10440046.2012.672376.

Kumar A., Gaind S., and Nain L. 2008. Evaluation of thermophilic fungal consortium for paddy straw composting. Biodegradation, 19: 395-402.

Lanna N.B.L, Silva P.N.L., Colombari L.F., Corrêa C.V., and Cardoso A.I.I. 2018. Residual effect of organic fertilization on radish production. Horticultura Brasileira 36: 047-053.

Lee C, Park J., Kim B., Seo J., Lee G., Jang S., and Koh H. 2015. Influence of Multi-Gene Allele Combinations on Grain Size of Rice and Development of a Regression Equation Model to Predict Grain Parameters. J. Rice 33 (8) pp 1-10.

Lithourgidis A.S, Matsi T., Barbayiannis N., and Dordas C.A. 2007. Effect of liquid cattle manure on corn yield, composition, and soil properties. Agronomy J., 99: 1041-1047.

Maftoun M. and F. Moshiri, 2008. Growth, mineral nutrition and selected soil properties of lowland rice, as affected by soil application of organic wastes and phosphorus. J. of Agric. Sci. \& Technol. 10: 481-492.

Mamrutha H.M., Sharma D., Kumar S., Venkatesh K., Tiwari V., and Sharma I. 2017. Infuence of diurnal irradiance variation on chlorophyll values in wheat: A comparative study using diferent chlorophyll meters. National Academy Science Letters, 40, 221-224.

Man L.H., Khang V.T., and Watanabe T. 2009. Improvement of soil fertility by rice straw manure. Omonrice 16: 71-80.

Mandal K.G., Misra A.K., Hati K.M., Bandyopadhyay, and Mohanty P.M. 2004. Rice residuemanagement options and effects on soil properties and crop productivity. Food, Agriculture \& Environment, Vol. 2 (1) : 224-231.

Nurrizki A.R. 2012. Effect of doses of organic and biofertilizers on yields of lowland rice (Oryza sativa L). Institut Pertanian Bogor. Bogor.

Padilla F.M., Peña-Fleitas M.T., Gallardo M., and Thompson R.B. 2017. Determination of sufciency values of canopy refectance vegetation indices for maximum growth and yield of cucumber. European Journal of Agronomy. 84, 1-15. 
Prasertsak A. and Fukai S. 1997. Nitrogen availability and water stress interaction on rice growth and yield. Field Crops Research. Vol. 52, Issue $3: 249-260$.

Rachman A., Rochayati S., dan Setyorini D. 2009. Soil fertility management technology for rice farmers : Indonesian experience. https://www.slideserve.com/kenna/soil-fertility- managementtechnology-for-rice-farmers-indonesian-experience .

Riyani R., Radian, and Budi S. 2013. Effect of various organic fertilizers on the growth and yield of rice in tidal land. Journal Science of Agricultural Student. 2 (2).

Salisbury F.B. and Ross C.W. 1995. Crops Physiology. 4th ed. Wadsworth Publishing Company, California.

Setiawati M.R., Damayani M., Herdiyantoro D., and Suryatmana P. 2019. The Role of Azolla pinnata and Biofertilizer on Organic Rice Farming. Academic Journal of Science. 09(01):211-

220. http://www.universitypublications.net/ajs/0901/html/M8K185.xml

Singh B., Singh Y., Ladha J.K., Bronson K.F., Balasubramanian V., and Singh J. 2002. Chlorophyll meter and leaf color chart-based nitrogen management for rice and wheat in North Western India. Agron J; 94:821-9.

Sinha S.K., Verma D.C., and Dwivedi C.P. 2002. Role of green manures (Sesbania rostrata) and biofertilizers (Blue-green Algae and Azotobacter) in rice-wheat cropping systems in the state of Uttar Pradesh, India. Physiology and Molecular Biology of Plants 8:105-110.

Soda W., Noble A.D., Suzuki S., Simmons R., Sindhusen L., and Bhuthorndharaj S. 2006. Cocomposting of acid waste bentonites and their effects on soil properties and crop biomass. J. of Environmental Quality 35: 2293-2301.

Syafi S. 2008. Morphological and physiological responses of seeds of various Jatropha genotypes (Jatropha curcas L.) to drought stress. IPB. Bogor.

Yang W., Li M., and Nick S. 2010. Estimating nitrogen content of cucumber leaves based on NIR spectroscopy. Sensor Letters. 8, 145-150. 